Meta

Journal des traducteurs

Translators' Journal

\title{
On the Evolution of Interpreting Strategies in Simultaneous Interpreting
}

\section{Alessandra Riccardi}

Volume 50, numéro 2, avril 2005

Processus et cheminements en traduction et interprétation Processes and Pathways in Translation and Interpretation

URI : https://id.erudit.org/iderudit/011016ar

DOI : https://doi.org/10.7202/011016ar

Aller au sommaire du numéro

Éditeur(s)

Les Presses de l'Université de Montréal

ISSN

0026-0452 (imprimé)

1492-1421 (numérique)

Découvrir la revue

Citer cet article

Riccardi, A. (2005). On the Evolution of Interpreting Strategies in Simultaneous Interpreting. Meta, 50(2), 753-767. https://doi.org/10.7202/011016ar
Résumé de l'article

L’interprétation simultanée est une compétence procédurale dont le développement peut être observé à travers les changements intervenant sur le plan des compétences implicites et des connaissances explicites. C'est une activité ciblée qui peut être analysée sur la base des stratégies utilisées par l'interprète au service d'une intention de communication. D'abord pendant ses études et ensuite au cours de sa carrière professionnelle, l'interprète développe, renforce et continue à perfectionner un comportement stratégique individuel fondé sur des stratégies qu'il introduit consciemment ou inconsciemment. Les stratégies sont considérées comme un instrument utile non seulement pour décrire le processus de l'interprétation mais également les aspects didactiques, permettant d'orienter les études vers le développement d'automatismes spécifiques pour l'interprétation simultanée. 


\title{
On the Evolution of Interpreting Strategies in Simultaneous Interpreting
}

\author{
ALESSANDRA RICCARDI \\ University of Trieste, Trieste, Italy \\ riccardi@sslmit.units.it
}

\begin{abstract}
RÉSUMÉ
L'interprétation simultanée est une compétence procédurale dont le développement peut être observé à travers les changements intervenant sur le plan des compétences implicites et des connaissances explicites. C'est une activité ciblée qui peut être analysée sur la base des stratégies utilisées par l'interprète au service d'une intention de communication. D'abord pendant ses études et ensuite au cours de sa carrière professionnelle, l'interprète développe, renforce et continue à perfectionner un comportement stratégique individuel fondé sur des stratégies qu'il introduit consciemment ou inconsciemment. Les stratégies sont considérées comme un instrument utile non seulement pour décrire le processus de l'interprétation mais également les aspects didactiques, permettant d'orienter les études vers le développement d'automatismes spécifiques pour l'interprétation simultanée.
\end{abstract}

\section{ABSTRACT}

This paper examines simultaneous interpreting (SI) from the viewpoint of procedural competence, whose evolution may be followed and monitored through the changes intervening within implicit and explicit tasks performed. As a goal-oriented communicative activity, SI may be analysed through the strategies applied to achieve the communicative goal. The interpreter, first during his studies and then throughout his career, develops and constantly refines a strategic behaviour integrating conscious and unconscious strategies. Strategies are a dynamic concept, useful not only for the description of process-oriented aspects of SI, but also as a teaching tool orienting the study and for devising exercises that help automatize specific interpreting solutions.

\section{MOTS-CLÉS/KEYWORDS}

interpreting strategies, implicit competence, procedural knowledge, simultaneous interpreting

\section{Introduction}

Half a century ago, in the 1950s, the first manuals and articles on conference interpreting appeared (Herbert 1952, Rozan, 1956). At that time, the first generation of modern interpreters must have felt the urge to collect and systematize their experience and knowledge of consecutive and simultaneous interpreting, gained working experience within international organizations for many years and passed it on to future generations of interpreters. Since there was an increasing demand for and interest in the profession, the time was ripe for recoding in written form what they had already been teaching orally in interpreting classes. The publications of those years signalize, moreover, a change in attitude of interpreters. Conference interpreting is no longer merely considered an implicit competence, a skill - difficult to explain and 
put into words and whose teaching is even more difficult, if not impossible - but also a declarative knowledge, rising into consciousness that can, therefore, be verbalized. This shift can be illustrated as a move away from the standpoint "interpreters are born, not made" towards the acknowledgement that conference interpreting is a skill that can be taught.

The first articles and manuals entail detailed descriptions of the profession and its different modalities, learning advice and methods, but also prescriptive comments exemplified with personal anecdotes about how to tackle the tasks of consecutive and simultaneous interpreting. The basic principles outlined emphasize - in addition to the importance of language proficiency which was the conditio sine qua non - that interpreting is more than simply transferring words from one language into another, first of all it is understanding the meaning, the sense of what is being said before delivering it into the target language. To concentrate on the message, the interpreter has to be well acquainted with the topic at hand and integrated in the communicative setting, to exploit not only the verbal information, but all other information implicit in the event. This position was further accentuated by the Paris School culminating in the théorie du sens.

Rem tene, verba sequentur, take care of the sense and the message will take care of itself, Cato's quotation could be the motto inspiring the activity of the first generation of interpreters, consecutive interpreters who had developed new skills to become, sometimes reluctantly, simultaneous interpreters. Actually they were first of all language experts and by necessity had adapted their language competence, world and professional knowledge to the new environment they were working in. The excellent mastery of their mother tongue and foreign languages together with their background knowledge and the working conditions had shown them, from the very beginning, that the most important objective within a conference or a meeting was to establish communication between the participants, to make the message flow in the most effective manner under given circumstances. This may be achieved in different ways and especially, to preserve idiomaticity in the target language and avoid interferences from the source text, without adhering too closely to source textstructures. Their intuition was difficult to transmit in interpreting classes where students had rarely acquired their language skills in natural conversational, but rather in formal, settings and had little functional practice so they tended to translate word for word because they were uncertain about the meaning of the source text. To change students' translating behaviour trainers would repeatedly stress the importance of understanding the message and not rely solely on the words heard.

Fifty years later, the social, professional and teaching environments have changed, of course. The constant evolution of the profession, new modalities, together with the mushrooming of conference interpreting programs have led to an increasing number of students willing to become conference interpreters, but who nonetheless show the same weaknesses as in the past, often lacking the necessary background with respect to language proficiency and world knowledge, also because their personality traits may not be suited to the job. Consequently, trainers, as happened in the past, are facing interpreting classes with students possessing very differentiated patterns of foreign language acquisition and proficiency, either because selection is not always possible or because entrance tests do not ensure a comparable level of language competence and aptitude among the new student population. In 
addition, an active foreign language exercises such a great fascination that students will not give up this challenge easily to concentrate exclusively on passive languages. They will struggle very hard to attain sufficient mastery to be able to interpret into their active language, even though the path may be very long to achieve a fluent and faithful rendering of the source message in a foreign language. Selecting text-types and communicative settings may reduce the scope of the task; nevertheless, the amount of knowledge and competence required to reach a fluent output in the B language is formidable. The task may not appear worthwhile with respect to the time and effort required to reach it. Later on, once their studies are finished, they may end up interpreting simultaneously only into their A language or they may change professions, but even then, the rigorous discipline they have undergone to attain their linguistic, communicative and interpreting skills will result in competence they can always draw upon, albeit in different social and professional environments.

While the basic principles of simultaneous and consecutive interpreting have remained consistent through the decades, teaching methods have evolved incorporating results and insight from other disciplines and adapted to the changing working environment. Nowadays, not only are new interpreting forms rapidly gaining ground, but also requested language combinations differ from the past, the most striking example being the EU institutions, before and after enlargement.

Conference interpreting trainers in Italy, and likely elsewhere too, are confronted with the challenge of applying teaching methods that will lead to the acquisition of interpreting skills in the most efficient way within the prescribed time. Together with constant updating, the objective is to conceive a method applicable to different domains or topics, although in most cases language skills and encyclopaedic knowledge will not be up to the mark. To this end, an understanding of how the processes underlying SI are developed and acquired is essential, because it offers explanations of what is happening and what must be concentrated on during training. The strategies applied to achieve the communicative goal intrinsic to simultaneous interpreting are useful in this respect, because, while showing the relation between the original discourse and the interpreted text, they can indicate what interpreting solutions have been applied by the interpreter, taking into account the communicative setting in which they were carried out. In addition to strategies, norms are another possible approach to the interpreted text (cf. Shlesinger 2000), the difference between the two lying in their dynamic or static character. Strategies aim at highlighting the process, they are process-oriented, while norms are the rule behind the strategy; their application can be detected in the interpreted text, they are product-oriented. In this paper, the process-oriented approach is chosen and SI is examined from the viewpoint of procedural competence, whose evolution may be followed and monitored through the changes intervening within implicit and explicit tasks performed.

\section{SI as procedural competence}

Speaking and listening in the mother tongue or in a very well-known language are spontaneous processes requiring very little effort. However, we often tend to forget how long it has taken to learn them, how many exercises, drills, errors they have been through, how much work and concentration has been needed to reach the present state of ability and knowledge. 
Every time we listen to somebody speaking, we enter a new world of sounds, words and images. From a continuous flow of sounds, we segment strings of phonemes and group them into syllables, words, sentences. We recognize meaningful units. To do so, we draw on cognitive resources like memory and attention and activate the cerebral areas where our knowledge of the language, the world, communicative events, culture and the subject matter as well as their relevant connections are stored. It is then possible to understand what is being said and, during this process, we form concepts and thoughts. During the listening process our role is mainly passive because we are exposed to the linguistic-communicative behaviour of the speaker, to his/her choice of language and style. Nevertheless, to extract meaning from the utterances heard, our cognitive activity becomes reactive. We react to what we hear and this reaction is possible only because we are actively constructing a concept, an image of what is being said.

Speaking we proceed in the opposite direction. We transform our thoughts into sounds, words and sentences to make ourselves understood. From our stock of language options, we choose those elements from our lexicon, syntax, prosody we consider best suited to carry our intended meaning. While we communicate, we perceive and observe the effect of what we are saying on our interlocutor, listener or audience. Their reactions, movements and expressions are a useful feedback because they enable us to act or change our plans accordingly and better to organize our speech.

Speaking and listening are such ordinary activities that while performing them we are hardly ever aware of the complex mechanisms they are based on. Only when there is a disruption, when we misunderstand something or we miss a link in what we hear, or when we don't find a suitable expression and we have to pause before continuing to speak, we become aware of the construction and deconstruction of meaning operations on which we rely while carrying them out. Even then, it is difficult exactly to recognize the cause of the disruption; what we notice is that there is an interruption in the flow of what we are saying or understanding.

These processes become more and more apparent during SI whose learning and training is based on the same processes. Compared to monolingual communication, SI is an unnatural form of communication, whose main peculiarity - in addition to its bilingual nature, common to all oral and written translation forms - is given by the time pressure under which it is carried out.

The interpreter reproduces the speech pronounced in the source language (SL) in the target language (TL) keeping the distance from the speaker as short as possible. The time lag or décalage between the two speeches may vary according to the language pairs involved, the source text density and pace, the speaker's and the interpreter's style. While producing the interpreted text (IT), the simultaneous interpreter is also listening to and processing the following speech segments, therefore dividing his/her attention among these processes. SL and TL are concurrently activated, but their activation thresholds need to be held at different levels (Paradis 1994a) to prevent interference with each other and to favour their active or passive use. Short term memory is constantly exploited for storing information in the SL and retrieving it in the TL.

The simultaneous activation of different cognitive processes makes SI a skill, an implicit competence, procedural knowledge, whose components and processes are interconnected. 
Process knowledge is knowing how to do something or learning connections between stimuli and responses and subserves motor or cognitive skills; it is the knowledge of how to perform a task, the know-how, and is directly applied to that task. It includes a set of sequences and determines actions to be carried out for each part of the sequence without conscious decision; consequently it is their concurrent taking place that leads to the accomplishment of the task. Procedural memory is linked to actions and can be used without conscious thinking, therefore, it is not easily verbalized. Examples of procedural learning are learning to ride a bike or learning to play the piano. Declarative knowledge by contrast is descriptive, it is knowing "that"; it entails the basic information for a specific situation, therefore declarative memory can be put into words. While knowledge about grammar rules is declarative, the spontaneous application of these rules is procedural.

To master the bilingual communicative activity of SI, the cognitive processes required to have been internalized and automatized by the interpreter, becoming a skill, procedural knowledge, and their activation occurs to a great extent beyond awareness. The natural, effortless flow of speech produced by many professional simultaneous interpreters may obscure the fact that their effortlessness has been acquired through long practice. Nevertheless, a sudden disruption, a longer pause or an error reveal that not all sequences of the process occur automatically, but are also the result of on-line processing that may end up in cognitive overload. During SI, both automatic, implicit components and non-automatic, explicit components of memory come into play. Implicit memory is an unconscious form of memory; it is remembering something without being aware that you are remembering it. It is acquired incidentally, not focusing attention on what is internalized, and is used automatically. The implicit components of a task are acquired through repeated exposure and practice (Schacter 1987). Declarative memory is learned consciously focusing on what is to be retained and concerns everything that can be represented at conscious level, its contents can be recalled (Paradis 1994b). Declarative memory is flexible and integrates various information. On the other hand, procedural memory is inflexible, available only for very specific tasks.

At the beginning of their SI-classes, trainees will once again experience the complexity of the cognitive processes underlying listening and speaking and have to learn new procedural knowledge. Not only will they have to learn to use two languages simultaneously, but they will do so under completely new communicative circumstances. What and how they express will be no longer the result of their free choice, but will depend to a great extent upon the speaker. Their language production is constrained by numerous factors and consequently they may no longer rely on their usual action plans. Finally, the speech they will hear is not targeted upon them, but upon the speaker's listeners. This new communicative setting requires new abilities. Therefore, learning SI requires reorganization of knowledge encompassing all stages of language reception and production, from phoneme perception to the understanding of an utterance and its recasting to produce the phoneme output, the IT, which will in the TL replace the speech in the SL. Every single utterance pronounced by the interpreter is the result of knowledge restructuring to adapt to SI conditions and circumstances. Furthermore, the whole process is conditioned by individual knowledge organization both at semantic and pragmatic level. 


\section{The development of interpreting skills}

The aim of teaching conference interpreting is to transform students' language skills, their present implicit competence, into new, implicit, procedural competence enhancing at the same time their declarative knowledge, their knowledge of different subject matters, such as economy, EU policies or international institutions. Declarative knowledge is achieved through deliberate learning by focalized attention and integrates information from various modalities; history, geography, but also terminology are cases in point. Procedural knowledge relates to action programmes and procedures, typical examples being playing an instrument by ear, language production, words used in context, language structures; they are all the result of implicit automatic processes.

The detection of differences in knowledge organization between professionals and students may be a starting point for explaining failures, omissions or errors in SI and may indicate specific areas on which SI-training and study should concentrate, since better knowledge organization closely correlates with reaction times and results in more rapid access to knowledge already at the level of word recognition.

Studies from Moser-Mercer (1997; Moser-Mercer et al. 2000) investigating knowledge organization in novices and experts, interpreting students and professionals, point to the differences in their organization of declarative and procedural knowledge which would explain differences in performance. The main feature detected in professional interpreters was a greater overall contextualization ability. For example, they were better able to link their semantic interpretation to the context of a speech and to establish more associative connections within their factual knowledge. Furthermore, results for schematic knowledge showed that professionals had developed schemata for different types of speech, negotiating situations, texts and paragraphs into which they have embedded individual utterances. At comprehension level, professionals were rapidly able to update their mental models and distinguish between important and secondary information. They applied planning strategies leading to rapid access of lexical, syntactic and semantic choices as well as choice of register and prosody and had more processing capacity available for monitoring. By contrast, students' results revealed that semantic interpretations were often entirely unrelated to the context, because they tended to treat each utterance or sentence in a more isolated manner and often failed to establish discourse links. Altogether, the studies showed that professionals' performance was more automatic and unconscious compared to that of novices and stressed the significance of automation of SI components to master SI skills, because through the automation of parts of the process, interpreters can overcome common processing limitations making optimal use of available processing capacity.

Studies on verbal attentive strategies (Paradis 1990) and on cerebral lateralization suggest, in fact, that practicing SI induces a dynamic modification of cerebral attentive strategies regarding the language pair involved. SI training leads, therefore, to an unconscious process of cerebral reorganization not only of linguistic but also of attentive strategies (Fabbro and Gran 1997) indicating that, in addition to linguistic factors, non-verbal factors affecting performance should be taken into account.

To reach the objective of the application of cognitive and linguistic strategies, Laura Gran (1998), for example, advocates a gradual approach to the acquisition of 
SI-skills beginning with exercises training one skill at a time, such as text analysis, abstracting, paraphrasing, and moving subsequently over to the whole task. At a later stage, training will be devoted to particularly difficult or complex parts of the interpreting process - speakers' pronunciation, speed, density of information, specialized terminology, rhetoric. Gran stresses that text analysis, conceptualization and reformulation mechanisms are too complex to be carried out at conscious level and all at the same time, nevertheless, they may become automatic through practice and will then be assimilated as procedural knowledge. Therefore, automatic reactions are of paramount importance for interpreting as they are likely to intervene to a much greater extent than is usually believed (Gran 1998).

As with any other skill, learning SI proceeds gradually and, because of its procedural character hindering conscious detection of underlying mental operations, studies are needed to shed light on its development.

\section{Studies in interpreting}

Given the multitude of variables involved, the study of IT is a challenging enterprise. Interpreting research has not yet been consolidated and lacks established methods and investigation tools. So far a multiplicity of approaches have been developed and methods have often been imported from neighbouring disciplines - translation studies, linguistics, psycholinguistics, social sciences and humanities - and adapted to cope with the interpreting situations (cf. Gile et al. 2001).

To investigate conference interpreting empirically, many studies have chosen either an experimental or a case study approach, sometimes a combination of the two. By 'case studies' are meant those studies whose objective is the description or evaluation of consecutive or simultaneous interpretations when they occur in their 'natural' environment. They are chosen when the aim is to describe the variables determining the interpretation setting globally and how these may influence the ITs. In these studies, a complete description of the event is the starting point for analysing ITs. The amount of data collected is huge and so is the work necessary to analyse it, but the results gained give a clear picture of what happens during a conference from different viewpoints. The results cannot be generalized, but they may help validate, confute or question existing theories and may point to new research ground. A drawback may be that they cannot be replicated nor can data be compared. The recordings, however, may be used for other experimental studies.

Another option is provided by experimental studies. The term 'experimental' refers to the artificial, laboratory conditions in which they are carried out; the variables chosen are determined by the investigators. The greatest drawback of experimental studies is their lack of ecological validity; the communicative setting is missing or at least many variables are not present. The advantage is that variables are kept under control and specific hypotheses may be tested on a sample of subjects; replication is possible. The sample chosen, professionals or advanced interpretation students, determine the study's scope. Results achieved always require further investigation. Certain trends may in any case be identified and used for further investigation or hypothesis testing. The examples cited in the following section are all taken from experimental studies. 


\section{Skill-based and knowledge-based strategies}

A viable method for observing the evolution of implicit and explicit components as well as the interaction of automatic and non-automatic skills in SI, is the comparison of students and professionals. Differences and similarities in their SI performance highlights the evolution and acquisition of SI competence. In a study comparing interpreting results of advanced interpreting students and professionals, Riccardi $(1996,1998)$ pointed to the interaction of two main categories of strategies during SI, knowledge-based strategies and skill-based strategies.

Skill-based strategies may be defined as all those strategies governed by stored patterns of automatic responses whose application is triggered by the recognition of a well-known stimulus within the communicative event. They are the result of procedural knowledge and have been internalized and automatized by the interpreter. Their use confers spontaneity and fluency upon output. Therefore, they may come into play at all levels - pragmatic, semantic, textual or morphological - and are closely dependent on the interpreter's knowledge organization and SI experience.

Welcoming, greetings, thanks, the introduction of different points of an agenda are immediately recognized as recurrent, stereotypical parts of a conference by the interpreters, who will resort to their store of ready-made phrases to interpret them into the TL. At the same time, they will select information units separating known information, usual in a given communicative setting, from new information conferring a unique character upon a speech portion, such as names and specific references, devoting greater attention to the latter.

In the following SI-examples by professional interpreters, it is difficult to notice differences from a speech produced in a monolingual setting; the various processes (listening, elaboration, production) are carried out effortlessly. The use of routine expressions for the verb freuen, the rearrangement and anticipation of information units to avoid the bottleneck of the verb at the end of the subordinate clause and the short pauses inserted all indicate the implementation of skill-based strategies.

Ich freue mich, dass ich heute hier die Ehrenbürgerwürde Berlins, der Hauptstadt des wiedervereinigten Deutschland, entgegennehmen darf.

Professionals

Sono particolarmente felice di poter essere qui oggi ad accettare la cittadinanza onoraria di Berlino, la capitale della Germania riunificata

Sono molto lieto di ricevere oggi la cittadinanza onoraria di Berlino, la capitale della Germania riunificata

Compared to the following delivery of student-interpreters, who have already attended SI courses but still lack training and experience, in addition to greater difficulties in rendering the same text portion, interpreting students show a tendency to split information units uttering them separately while waiting for the verb.

Students

E' un onore per me essere qui presente oggi

aver ricevuto la cittadinanza onoraria a Berlino

Vorrei esprimere la mia gioia nell'essere qui oggi a

Berlino, la città, la capitale della Germania riunificata vorrei ringraziare il

Parlamento per questa onoreficenza 
Interpretation of recurrent formulas within a text or a given communicative setting are a very clear example of automatized strategies, but since skill-based strategies are the result of implicit competence, whose most remarkable feature is to remain at subconscious level, their presence may be hardly detected at conscious level. Hesitation, pauses, slowly-constructed sentences are, by contrast, the result of explicit knowledge application. At language-pair level, interpreters have elaborated strategies for easy and rapid language switching, beginning at the simple word level and becoming more sophisticated in rendering morphosyntactic structures, conjunctions, register and prosody. Basic skilled-based strategies at language-pair level come into play while interpreting, for example, non-marked sentence structures, verbal collocations, phrasal verbs of a given SL. The way in which and the rapidity with which they are rendered in the TL reveal the extent to which they already have been acquired and internalized (Riccardi 1998), so that they favour a fluent output when interpreting into a structurally different language, for example from a Germanic language with verb at the end structure to a language with SVO order.

An example of such basic language structures are German Funktionsverbgefüge, structures with functional verbs, they are fixed collocations of substantive and verbs, of substantive, preposition and verb, or of adjective, preposition and verb. In functional verb structures, the substantive is always followed by a certain verb or a very small choice of verbs and most semantic information is carried by the substantive, while the verb adds very little or no information at all to the content and, therefore, to the comprehension of the sentence. Their occurrence in secondary clauses helps the interpreter to anticipate the verb in final position during SI into a SVO-language, because as soon as the substantive is heard, the number of possible verb-options is considerably reduced. In the following examples, after having heard Brücke, the verb schlagen occurs automatically, in the same way as after hearing Entscheidung the viable option, given the co-text, will be treffen.

Die Brücke zur Regierungskonferenz 2004 kann nur eine breite öffentliche Diskussion im Vorfeld dieser Konferenz schlagen

Deshalb ist das sicherlich eine Entscheidung, die zu den wichtigsten gehört, die das Haus in seiner gesamten Geschichte zu treffen hat

World, specialized and factual knowledge together with language and communicative competence allow the interpreter to understand the message and produce the IT. Known words are always linked with concepts, with declarative knowledge, therefore, the better the knowledge organization, the more rapid meaning recovery and production will be. The greater rapidity and effectiveness with which certain structures or text segments are interpreted may be supposed directly to correlate with conceptual and linguistic knowledge organization optimized for SI.

Information density, speed of delivery, foreign accent are variables of the original speech that can be assessed through objective or subjective values. While the former may be measured instrumentally, the latter is a function of individual knowledge organization. Hence, the importance for trainers of having reference or standard values of text comprehension and production at their disposal, because students' deviations from reference values indicate that certain knowledge structures and skills need improvement. The aim of teaching is to make objective and subjective values coincide and, to this end, interpreting classes are modulated. Exercises proceed gradually 
from standard discourse with standard delivery pace and information density towards discourse containing to a variable extent occurrences which may hinder the task, such as increased speed, numbers, wrong prosody, complex structures, specialized terminology.

Knowledge-based strategies are the other group of strategies employed during SI; they differ from skilled-based strategies because their activation is the result of conscious analytical processes. They come into play when actions must be planned on-line, because no automatic response is found or because something has caused a momentary memory overload. Consequently, ST processing and/or IT production require constant attention and the ability to divide cognitive resources among the processes as has been stressed by Gile (1995) in his effort models. The reasons for this momentary breakdown or cognitive overload are numerous, from high delivery speed, high information density, read texts, unknown terms or concepts, left branching for strings of modifiers or embedded sentences. The following examples in German taken from official speeches present strings of modifiers (1-3) and a subordinate clause (4) whose meaning development is not easily inferable because of the delayed verb. The interpreter has to decide whether he/she will wait for more information or proceed chunking the message. The increased amount of information in the left part of the sentence or a phrase needs to be stored in working memory waiting for the information that will complete the picture or the mental image of what is being interpreted.

1. auf dem Weg in ein freies, friedliches und ökonomisch erfolgreiches 21. Jahrhundert

2. Ich setze darauf, dass das Europäische Parlament heute die Tür für die zehn Staaten vollends aufmacht. Ich bin mir aber bewusst, dass in der Stunde der Entscheidung nicht bei jedem hier im Hause und nicht bei jedem in der europäischen Öffentlichkeit jeder Zweifel am Erweiterungsprozess ausgeräumt ist

The following example is taken from a study (Bevilacqua 2003) analysing IT by professional interpreters with the aim of recognizing strategies adopted to contrast the delayed utterance of the verbal phrase, in the following example zum Thema gemacht hat.

Ich glaube, es sollte auch vermerkt werden, dass das Europäische Parlament wie credo che vada anche segnalato che il

kaum ein anderes in Europa schon in der Zeit des Kalten Krieges immer wieder Parlamento Europeo (1") come nessun altro in Europa >già nei tempi della guerra

die offene Wunde der Spaltung Europas zum Thema gemacht und für eine fredda< (4") aveva sempre parlato > della

europäische Zukunft plädiert hat, (in der die Völker in freier Selbstbestimmung...) ferita aperta della divisione dell'Europa e aveva sempre richiesto un futuro dell'Europa

The interpreter first follows the source-text structure, but interrupts the interpretation for around 4 seconds to wait for meaning disambiguation and then resumes output at a rapid pace. The changes in delivery speed and rhythm clearly signalize when there is a slowdown in elaboration and retrieval, and controlled, conscious knowledge strategies are adopted and again when skill-based strategies are at work.

The following example together with the IT of two interpreters shows different strategies adopted. Interpreter a), for example intersperses his output with longer 
silent pauses, used as a rhetorical device, and then resumes discourse producing a structured and fluent output. Interpreter b) instead, follows the ST structure more closely and opts for anticipatory strategy, successfully.

O) Ich habe in der vergangenen Woche in Ungarn in einer Rede darauf hingewiesen,

a) (per la prima volta già nel 56) la settimana scorsa in Ungheria la settimana scorsa in Ungheria

O) dass wohl allen europäischen Politikern meiner Generation

a) durante un mio discorso ho indicato che 4"

b) ho ricordato in un discorso come tutti i politici europei

O) die Hilferufe der Führer des ungarischen Aufstandes 1956

a) tu. tti i leader politici

b) della mia generazione ricordano perfettamente il grido

O) noch im Ohr sind, dass wir sie nicht vergessen können und dass diese Hilferufe auch heute

a) della nostra generazione hanno sicuramente ancora nell'orecchio le grida d'aiuto della

b) la richiesta d'aiuto dei rivoltosi ungheresi del 56 una richiesta d'aiuto che

O) (fast 50 Jahre später für die europäischen Demokratien immer noch)

a) rivoluzione del 56 queste richieste d'aiuto che non possiamo dimenticare che anche

b) non possiamo dimenticare ed è quel grido quella richiesta d'aiuto al quale oggi

The following examples are taken from a study comparing deliveries of professional interpreters of a read text (Ferrusso 2002). Both groups were briefed about the content half an hour earlier, but one group also received the written text for preparation. Results show that without the text there was a greater tendency to generalize the content and omit irrelevant information as well as to adopt fewer reformulation strategies, such as chunking, morphosyntactic changes or recasting. The ITs with the text were, on the contrary, more specific and more closely followed the textual structure of the source speech. Results indicate therefore whether and how cognitive load is alleviated through the text and what strategies are applied under the two conditions. An example may clarify what has been noted. In this segment, disambiguation of content through the verb and object is delayed by the presence of two noun phrases and an embedded sentence:

In the worst-affected countries - where more than one in five adults are infected infrastructure, services and productive capacity are facing total collapse

Without text:

a) I paesi più colpiti registrano un tasso di 1 su 5 per quanto riguarda l'infezione e di fronte a queste prospettive dobbiamo interrogarci

b) In alcuni paesi un adulto su 5 viene colpito. In termini di servizi, molti paesi stanno andando incontro a un vero e proprio collasso.

c) I paesi più colpiti, in cui oltre un adulto su 5 sono infetti la capacità produttiva sta collassando in questi paesi

With text:

aT) In più, inoltre, l'impatto dell'AIDS è crescente e i paesi più gravemente colpiti vedono il contagio di uno su cinque con un grande impatto sull'infrastruttura e sulle capacità produttive 
bT) Nei paesi più colpiti, dove il tasso di infezione riguarda il 20\% degli adulti, il settore dei servizi e le capacità produttive si trovano davanti al crollo completo

cT) Nei paesi maggiormente colpiti dalla malattia, dunque, più di un adulto su cinque è infettato. Le infrastrutture, i servizi e la capacità produttiva si trovano dacanti un crollo totale

In the study of Riccardi (1998) comparing students and professionals, the overall result indicated that the former showed greater concern for the lexical level of ST and IT, while the latter made greater use of semantic and pragmatic information and fewer elements at, whatever level, phonological, lexical, syntactic or semantic, were sufficient to begin output production. On the whole, the greatest difference in their performances was detected in the extent to which skill-based strategies as opposed to knowledge-based strategies were implemented, thereby confirming the results of Moser (1997), who stressed the importance of automation of SI components.

\section{SI as a goal-oriented activity}

The results of the studies comparing students and professionals reveal the significance of knowledge restructuring and the automatization of certain components of the SI process for the development of the SI skill. In this respect, automatization is the result of the repeated application and assimilation of target-oriented solutions. The production of the IT from the ST is, therefore, the result of decision-making processes, the acquisition of which began during the first class of SI.

To achieve the goal of interpreting simultaneously, trainees learn to develop strategic behaviour encompassing all levels of language production and perception. Divided attention and décalage, the activation of the relevant knowledge of a subject matter, selection of information, the choice between different options of the TL for interpreting syntactical structures of the SL, rapid switching from form-based interpreting when confronted with numbers, technical terms, proper names back to meaningbased interpreting, are all examples of internalized strategies needed to perform SI. They have become second nature and most interpreters will keep developing them during their career.

The objective of a strategy is not only the reaching of a goal but that of reaching it "in some optimal way (e.g. quickly, effectively, or with low cost)" (van Dijk and Kintsch 1983: 62). Conference interpreting is a goal-oriented activity directed towards the faithful reproduction of the source text in the TL under given circumstances. To achieve this goal, simultaneous interpreters' activity is conditioned by a wide range of factors beyond his/her sphere of influence. They may be determined by the topic chosen for the meeting, the kind of meeting, the delivery mode (impromptu speeches, or read speeches), rate of delivery, pronunciation, rhetorical style of the speaker, information density, audience, to name only some. Interpreting may, thus, be seen as a decision-making or problem-solving activity. Decisions, as has been indicated, are taken consciously or unconsciously at all levels of IT production. Therefore, the SI process may be regarded as based on strategic behaviour at all levels of IT production.

The relation between ST and IT, the changes in terms of structural reordering and recasting, décalage, omissions, additions, paraphrase, intonational stress etc. may be 
seen as the expression of this strategic behaviour, independently of the interpreters' conscious awareness. The difficulty in describing and teaching interpreting lies in its implicit, procedural character, which is neither transparent nor open to introspection. Many of the cognitive processes involved occur far too rapidly consciously to be noted.

\section{Strategies in SI}

The strategic behaviour of interpreters is a recurrent object of research into SI. Some studies examine the use of single, specific strategies such as anticipation (Lederer 1978; Moser 1978 Wilss 1978) while others adopt an overall approach (Kirchhoff 1976; Kohn and Kalina 1996; Kalina 1998). Gile (1995) uses the term of 'coping tactics' to refer to conscious solutions implemented by the interpreter to contrast processing capacity overload and knowledge base inadequacy.

The most common categorization distinguishes between comprehension, production, overall and emergency strategies. Comprehension strategies generally include, anticipation, segmentation, selection of information, stalling or waiting, while production strategies consist of compression, expansion, approximation strategies, generalization, use of linguistic open-end forms, morphosyntactic transformation and the use of prosody elements, such as pauses and intonation. Décalage and monitoring are counted among the overall strategies, while emergency strategies may include, for example, the omission of text segments, transcoding and parallel reformulation. As for every classification, strategy categories are not always homogeneous among researchers and sometimes the borders between comprehension and production or production and emergency strategies are blurred. The category 'production strategies' is, comprehensibly, the largest category, because it is made up of all occurrences noted comparing the ST with the IT.

If strategies are to be considered a viable tool for pointing to the transfer mechanisms intervening during the SI process and the results achieved, then, of course, categories will be open and can host numerous other strategies, depending on the kind of interpreting solution examined.

In a study comparing reformulation strategies in consecutive and simultaneous interpretation, Messner (2000) expanded the category additions to take into account discourse markers - connectives, rhetorical phrases, fillers - typical of spoken language. Some of the subclasses were, for example, markers of text segmentation (so, in this respect), markers stressing focal elements (exactly, correct, that is, I mean) markers signalling reformulation (in other words) and markers for modulation operations (to soften or strengthen the impact, maybe, sure, really), necessary to analyse and specify the various additions encountered.

\section{Conclusion}

Strategies have proved a useful instrument both in research and teaching, because they point to typical interpreting occurrences resulting from the SI process. They may, therefore, be grouped into general interpreting strategies, independent of the language pair used, or into language pair-specific strategies, taking into account solutions imposed by structural and lexical diversities of the languages used (Riccardi 1999). Again, the choice will depend upon the research or teaching aim. 
Results obtained from experimental studies on strategies may be usefully applied to training, to show students how many interpretations of a ST segment there may be and to evaluate the effectiveness and degree of equivalence obtained by different solutions. Moreover, strategies may be used to assess development and improvement in SI performance helping students to move away from the words towards the message.

\section{REFERENCES}

Bevilacqua, L. (2003): Posizione del verbo nelle lingue germaniche e interpretazione simultanea, unpublished dissertation, Trieste: SSLMIT.

VAN DijK, T. A. and KIntsch, W. (1983): Strategies of Discourse Comprehension, Orlando/London, Academic Press.

Ferrusso, P. (2002): Interpretazione simultanea con e senza l'ausilio del testo scritto: uno studio sperimentale, unpublished dissertation, Trieste: SSLMIT.

Fabbro, F. and L. Gran (1997): "Neurolinguistic Aspects of Simultaneous Interpretation," Conference Interpreting: Current Trends in Research (Y. GAMBIER, D. GILE and C. TAYlor eds.) Amsterdam/Philadelphia: John Benjamins, p. 9-27.

GiLe, D. (1995): Basic Concepts and Models for Interpreter and Translator Training. Amsterdam/ Philadelphia: John Benjamins.

Gile, D., Dam, H. V., Dubslaff, F., Martinsen, B. \& Schjoldager, A. (2001): Getting Started in Interpreting Research. Amsterdam/Philadelphia: John Benjamins.

Gran, L. (1998): “In-training Development of Interpreting Strategies and Creativity,” Translators' Strategies and Creativity (Ann Beylard-Ozeroff, Jana Králová \& Barbara Moser-Mercer eds.) Amsterdam/Philadelphia: John Benjamins, p. 145-162.

Herbert, J. (1952): Manuel de l'interprète, Genève: Librairie de l'Université, Georg.

Kalina, S. (1998): Strategische Prozesse beim Dolmetschen. Theoretische Grundlagen, empirische Fallstudien, didaktische Konsequenzen, Tübingen: Gunter Narr.

Koнn, K. and Kalina, S. (1996): “The Strategic Dimension of Interpreting," Meta, 41-1, p. 118-138.

Kirchноғғ, H. (1976): "Das Simultandolmetschen: Interdependenz der Variablen im Dolmetschprozeß, Dolmetschmodelle und Dolmetschstrategien," Theorie und Praxis des Übersetzens und des Dolmetschens (W. Drescher \& Signe Scheffzek eds.), Bern/Frankfurt M.: Lang, p. 59-71.

Messner, C. (2000): Interpretazione Consecutiva e interpretazione simultanea: confronto e analisi delle strategie interpretative, unpublished dissertation, Trieste: SSLMIT.

Lederer, M. (1978): “Simultaneous Interpretation - Units of Meaning and Other Features," Language, Interpretation and Communication (David Gerver \& H. Wallace Sinaiko eds.), New York/London: Plenum Press, p. 323-332.

Moser, B. (1978): "Simultaneous Interpretation: A Hypothetical Model and Its Practical Application," Language, Interpretation and Communication. (David Gerver \& H. Wallace Sinaiko eds.), New York/ London: Plenum Press, p. 353: 368.

Moser-Mercier, B. (1997): “The Expert-Novice Paradigm in Interpreting Research,” Translationsdidaktik: Grundfragen der Übersetzungswissenschaft (Eberhard Fleischmann ed.), Tübingen: Gunter Narr, p. 255-261.

Moser-Mercier, B., Frauenfelder, U. H, Casato, B. \& Künzli A. (2000): "Searching to Define Expertise in Interpreting," Language Processing and Simultaneous Interpreting (Birgitta Englund Dimitrova and Kenneth Нyltenstam eds.) Amsterdam/Philadelphia: John Benjamins, p. 107-131.

Paradis, M. (1990): "Notes and Discussion. Language Lateralization in Bilinguals: Enough Already," Brain and Language 39(4), p. 576-586.

Paradis, M. (1994a): "Toward a Neurolinguistic Theory of Simultaneous Translation: The Framework," International Journal of Psycholinguistics, 10, n. 3 [29], p. 319-335. 
Paradis, M. (1994b): "Neurolinguistic Aspects of Implicit and Explicit Memory: Implications for Bilingualism and SLA," Implicit and Explicit Learning of Languages (Nick C. Elurs ed.), London, New York: Academic Press, Harcourt Brace, p. 393-419.

Riccardi, A.(1996): "Language-Specific Strategies in Simultaneous Interpreting," in New Horizons - Teaching Translation and Interpreting (Cay Dollerup \& Vibeke Appel eds.), Amsterdam/Philadelphia: John Benjamins, p. 213-222.

RicCARDI, A. (1998): "Interpreting Strategies and Creativity," in Translators' Strategies and Creativity (Ann Beylard-Ozeroff, Jana Králové \& Barbara Moser-Mercer eds.) Amsterdam/ Philadelphia: John Benjamins, p. 171-179.

RicCardi, A.(1999): “Interpretazione Simultanea: Strategie Generali e Specifiche," Interpretazione simultanea e consecutiva - problemi teorici e metodologie didattiche (C. FALBo, C. Russo \& F. Straniero eds.), Milano: Hoepli, p. 161-174.

Rozan, J-F. (1956): La prise de notes en interprétation consécutive, Genève: Librairie de l'Université, Georg.

SChaCter, D. L. (1987) "Implicit Memory: History and Current Status," Journal of Experimental Psychology: Learning, Memory and Cognition, 13, p. 501-518.

Shlesinger, M.(2000): "Interpreting as a Cognitive Process: How Can We Know What Really Happens?" Tapping and Mapping the Processes of Translation and Interpreting (Sonja TirkKonen-Condit and Riitta Jä̈̈sleläInen eds.) Amsterdam/Philadelphia: John Benjamins, p. 3-15.

WILss, W. (1978): "Syntactic Anticipation in German-English Simultaneous Interpreting," Language, Interpretation and Communication. (David Gerver \& H. Wallace Sinaiko eds.), New York/ London, Plenum Press, p. 343-352. 